\title{
Identification of a sterol mutant of Neurospora crassa deficient in $\Delta^{14,15}$-reductase activity
}

\author{
S. W. Ellis, ${ }^{1}$ M. E. RosE $^{2}$ and M. GRINDLE ${ }^{1 *}$ \\ ${ }^{1}$ Department of Molecular Biology and Biotechnology, University of Sheffield, Sheffield S10 2TN, UK \\ ${ }^{2}$ Department of Chemistry, Open University, Milton Keynes MK7 6AA, UK
}

(Received 20 February 1991; revised 7 June 1991; accepted 1 July 1991)

\begin{abstract}
A mutant (erg-3) of Neurospora crassa resistant to the polyene antibiotic nystatin was compared with its sensitive, wild-type parent to detect differences in sterol composition using gas chromatography-mass spectrometry. The major sterol in wild-type mycelia, comprising $80 \%$ of the total, was ergosterol. The major sterols in mutant mycelia, comprising $86 \%$ of the total, were $\Delta^{8,14}$-sterols. It is proposed that the nystatin-resistant strain is unable to synthesize ergosterol because it lacks $\Delta^{14,15}$-reductase activity as a result of a mutation in the erg-3 gene.
\end{abstract}

\section{Introduction}

The biosynthetic pathway of ergosterol, the major sterol of many fungal species, has been studied extensively (Mercer, 1984; Weete, 1989). Initial work, conducted mainly with the yeast Saccharomyces cerevisiae, identified numerous intermediates in the pathway by analysing mutants blocked at various stages of sterol biosynthesis (Fryberg et al., 1974; Bard et al., 1977; Trocha et al., 1977). Yeast mutants (designated erg) collectively are defective in almost every major biosynthetic step after cyclization of squalene (Parks et al., 1985); they include mutants defective in $\Delta^{8 \rightarrow 7}$ isomerization (erg2), 5(6) desaturation (erg3), 24(28) hydrogenation (erg4), 22(23) desaturation (erg5), C-24 transmethylation (erg6) (Bard et al., 1977) and C-14 demethylation (erg11) (Gollub et al., 1974). Mutants of filamentous fungi blocked at similar steps in the sterol biosynthesis pathway have also been isolated. For example, Grindle \& Farrow (1978) reported mutants of Neurospora crassa with gene defects affecting $\Delta^{8 \rightarrow 7}$ isomerization (erg-1), 24(28) hydrogenation (erg-2) and C-24 transmethylation (erg-4).

The biosynthetic pathway of ergosterol includes a $\Delta^{8,14}$-sterol intermediate formed as a result of the demethylation of lanosterol or 24-methylenedihydrolanosterol. The $\Delta^{14}$ double bond is then reduced to give the corresponding $\Delta^{8}$-sterol (Mercer, 1984). To date, no mutant with a block in the reduction of the $\Delta^{14}$ double bond has been reported in the literature. This paper identifies such a mutant of $N$. crassa; the mutant

Abbreviation: TMS, trimethylsilyl. (designated erg-3) was originally isolated by Grindle $(1973,1974)$ but the enzyme defect caused by the erg-3 gene was not determined.

\section{Methods}

Sources of strains. The wild-type 74-OR8-1 $a$ was obtained from the Fungal Genetics Stock Center, University of Kansas Medical Center, Kansas 66103 , USA. The mutant $\mathrm{erg}-3$ was derived from 74-OR8-1 $a$ by UV-mutagenesis (Grindle, 1974), and is available from the above Stock Center.

Growth of cultures. The wild-type and mutant were maintained on solid medium as described previously (Grindle, 1973). For sterol analysis, mycelium was grown to mid-exponential phase in liquid minimal medium (Vogel, 1964) at $26^{\circ} \mathrm{C}$ on a rotary shaker (150 r.p.m.), harvested by filtration, and washed twice with distilled water.

Sterol extraction and derivatization. Mycelium ( $2 \mathrm{~g}$ ) was acid-labilized by resuspending in 10 vols $0.1 \mathrm{M}-\mathrm{HCl}$ and heated at $100{ }^{\circ} \mathrm{C}$ for $20 \mathrm{~min}$. The acid-labilized mycelium was harvested by centrifugation, washed twice with $10 \mathrm{ml}$ of distilled water, and resuspended in $2 \mathrm{ml} 60 \%(\mathrm{w} / \mathrm{v})$ $\mathrm{KOH}$ in water, $3 \mathrm{ml}$ methanol and $2 \mathrm{ml} 0.5 \%(\mathrm{w} / \mathrm{v})$ pyrogallol in methanol (Parks et al., 1985). The mycelial suspension was homogenized with $0.5 \mathrm{~g}$ of glass beads $(0.45-0.5 \mathrm{~mm})$ in an MSE homogenizer for $4 \times 10 \mathrm{~s}$ and saponified at $85^{\circ} \mathrm{C}$ for $2 \mathrm{~h}$. After cooling, the nonsaponifiable lipids (sterols) were extracted with heptane $(3 \times 3 \mathrm{ml})$, dried over anhydrous sodium sulphate, and the heptane extract was analysed by UV-spectrophotometry at $210-300 \mathrm{~nm}$. The heptane extract was evaporated to dryness with warm nitrogen and the residue dissolved in a mixture of anhydrous pyridine, hexamethyldisilazane and trimethylchlorosilane $(7: 2: 1$, by vol.). The mixture was left overnight at room-temperature, and the resulting trimethylsilyl (TMS) sterol derivatives were analysed by gas chromatography and gas chromatography-mass spectrometry.

Gas chromatography (GC) and gas chromatography-mass spectrometry $(T C-M S)$. GC was performed on a Packard 437A gas chromatograph, 
A<smiles>CC(C)C(C)/C=C/C(C)C1CCC2C3=CC=C4CC(O)CCC4(C)C3CCC21C</smiles><smiles>C=C(CCC(C)C1CCC2C3=CCC4CC(O)CCC4(C)C3CCC21C)C(C)C</smiles>

$\mathrm{C}$<smiles>C=C(CCC(C)C1CCC2(C)C3=C(CCC12)C1(C)CCC(O)C(C)C1CC3)C(C)C</smiles>

$\mathrm{D}$<smiles>C=C(C)CCC(C)C1CCC2(C)C3=C(CCC12C)C1(C)CCC(O)C(C)(C)C1CC3</smiles>

$\mathrm{E}$

G<smiles>C=C(CCC(C)C1CC=C2C3=C(CCC21C)C1(C)CCC(O)CC1=CC3)C(C)C</smiles><smiles>C=C(CCC(C)C1CC=C2C3=C(CCC21C)C1(C)CCC(O)CC1CC3)C(C)C</smiles><smiles>CC(C)C(C)CCC(C)C1CC=C2C3=C(CCC21)C1(C)CCC(O)CC1CC3</smiles>

$\mathrm{H}$

Fig. 1. Deduced structures of sterols. A, ergosterol; B, episterol; C, obtusifoliol; D, 24-methylenedihydrolanosterol; E, ergosta$5,8,14,24(28)$-tetraene-3 $\beta$-ol; $\mathrm{G}$, ergosta-8,14,24(28)-trien-3 $\beta$-ol; $\mathrm{H}$, ignosterol. (F, not shown.)

fitted with a flame ionization detector, using a DB5 fused silica capillary column $(30 \mathrm{~m} \times 0.32 \mathrm{~mm}$ i.d., film thickness $0.25 \mu \mathrm{m})$. Analyses were conducted isothermally at $260^{\circ} \mathrm{C}$ with an injection teperature of $300^{\circ} \mathrm{C}$. The carrier gas was hydrogen with a flow rate of $4 \mathrm{ml} \mathrm{min}-1$. Peak areas were determined using a Shimadzu Chromatopac C-R3A data processor. GC/MS was performed on a VG 20-250 quadrupole instrument coupled to a Hewlett-Packard 5890 gas chromatograph. TMS derivatives were separated on a BP5 fused silica capillary column ( $12.5 \mathrm{~m} \times 0.33 \mathrm{~mm}$ i.d., $0.25 \mu \mathrm{m}$ film thickness; SGE) using a temperature programme of $230-260^{\circ} \mathrm{C}$ increasing at $5{ }^{\circ} \mathrm{C} \mathrm{min}^{-1}$. The carrier gas was helium and the pressure at the column inlet was 10 p.s.i. A cold on-column injector (SGE OCI3) was utilized and the column was coupled directly to the ion source of the mass spectrometer; ion source temperature $200^{\circ} \mathrm{C}$, electron energy $70 \mathrm{eV}$ and electron current $100 \mu \mathrm{A}$. Identification of sterols was based on comparison with authentic standards and by reference to published data on mass spectra and relative retention times of known sterols.

\section{Results and Discussion}

Ultraviolet spectrophotometry of sterol extracts from the mutant erg-3 showed an absorption maximum at $250 \mathrm{~nm}$ and a shoulder at $245 \mathrm{~nm}$, which confirmed the observations of Grindle \& Farrow (1978). Such a spectrum is characteristic of $\Delta^{8,14}$-sterols (Mercer, 1988). No absorption maxima at 293, 282 and $272 \mathrm{~nm}$ were apparent, indicating the absence of $\Delta^{5,7}$-dien-sterols. In contrast, the absorption spectrum of the wild-type sterol extract showed the presence of $\Delta^{5,7}$-dien-sterols.

The relative retention times of the major sterols and their abundance in terms of peak area (Table 1) were determined from chromatograms of TMS-derivatized sterol extracts. The structures of the major sterols were deduced from their mass spectra (Table 2), and are depicted in Fig. 1.
Table 1. Relative retention times and quantities of TMS-sterols in wild-type and erg-3 strains of N. crassa

\begin{tabular}{|c|c|c|c|c|}
\hline \multirow[b]{2}{*}{ Sterol $^{*}$} & \multirow{2}{*}{$\begin{array}{c}\text { Relative } \\
\text { retention } \\
\text { time }\end{array}$} & \multirow[b]{2}{*}{ Strain . } & \multicolumn{2}{|c|}{ Quantity } \\
\hline & & & Wild-type & erg-3 \\
\hline A & 1.26 & & 80 & - \\
\hline B & 1.46 & & 6 & - \\
\hline $\mathrm{C}$ & 1.56 & & 2 & 4 \\
\hline D & 1.79 & & 2 & 1 \\
\hline E & $1 \cdot 14$ & & - & 25 \\
\hline $\mathbf{F}$ & 1.29 & & - & 5 \\
\hline G & 1.33 & & - & 43 \\
\hline $\mathbf{H}$ & $1 \cdot 35$ & & - & 13 \\
\hline Other(s) & - & & 10 & 9 \\
\hline
\end{tabular}

* Structures shown in Fig. 1.

$\dagger$ Relative to cholesterol TMS ether as internal standard.

$\ddagger$ Expressed as area $\%$ of total sterols.

Mass spectral data confirmed that the major sterol (A) in the wild-type was ergosterol, comprising $80 \%$ of the total sterols. A minor sterol (B) was identified as ergosta7,24 (28)-dien-3 $\beta$-ol (episterol), by comparison with mass spectra from Osumi et al. (1978) and Howell et al. (1990). Trace amounts of sterols having retention times comparable with, and fragmentation patterns of, obtusifoliol (C) and 24-methylenedihydrolanosterol (D) as their TMS derivatives were also detected.

In contrast, there were no detectable amounts of ergosterol in the erg-3 mutant. In conjunction with the UV-spectrophotometric data, the GC-MS data verified the presence of $\Delta^{8,14}$-conjugated-dien-sterols. The TMS ethers of sterols $\mathrm{E}, \mathrm{F}, \mathrm{G}$ and $\mathrm{H}$, comprising $86 \%$ of the total sterols, each have mass spectra typical of $\Delta^{8,14}$-dien- 
Table 2. Mass spectra of major sterols as their TMS ethers in wild-type and erg-3 strains of N. crassa

Figures in parentheses are the abundances of the ions.

\begin{tabular}{|c|c|c|c|c|c|c|c|c|c|}
\hline Fragmentation $\dagger$ & Sterol $^{*}$ & A & B & C & D & E & $\mathbf{F}$ & G & $\mathbf{H}$ \\
\hline u $]^{+}$ & & $468(12)$ & $470(3)$ & $498(20)$ & $512(20)$ & $466(12)$ & $466(5)$ & $468(30)$ & $470(40)$ \\
\hline$[M-\mathrm{Me}]^{+}$ & & $453(2)$ & $455(8)$ & $483(37)$ & $497(28)$ & $451(3)$ & - & 453 & $455(12)$ \\
\hline$\left[M-\mathrm{C}_{3} \mathrm{H}_{7}\right]^{+}$ & & - & - & - & - & - & - & $425(10)$ & \\
\hline$[M-\mathrm{ROH}]^{+}$ & & $378(8)$ & - & - & - & $376(3)$ & - & - & $380(4)$ \\
\hline$[M-84]^{+}$ & & - & $386(10)$ & - & - & - & - & - & - \\
\hline$[M-\mathrm{Me}-84]^{+}$ & & - & - & - & - & - & - & $369(20)$ & \\
\hline$[M-\mathrm{ROH}-\mathrm{Me}]^{+}$ & & $363(65)$ & - & $393(55)$ & $407(95)$ & $361(100)$ & $361(38)$ & $363(15)$ & $365(75)$ \\
\hline$[M-S$ & & - & - & - & - & - & - & $343(7)$ & $343(4)$ \\
\hline$[M-\mathrm{SC}-\mathrm{H}(2 \mathrm{H})]^{+}$ & & - & $343(50)$ & - & - & $340(10)$ & - & - & - \\
\hline$[M-131]^{+}$ & & $337(53)$ & - & - & - & - & - & - & - \\
\hline$M-\mathrm{R}$ & & - & - & - & - & - & - & $335(16)$ & - \\
\hline$[M-\mathrm{R}$ & & - & - & $309(15)$ & $324(18)$ & $277(8)$ & $277(8)$ & $279(12)$ & - \\
\hline$[M-\mathrm{SC}-\mathrm{ROH}]^{+}$ & & $253(18)$ & $255(15)$ & - & - & - & - & $253(9)$ & $253(18)$ \\
\hline$[M-\mathrm{SC}-\mathrm{ROH}-\mathrm{H}(2 \mathrm{H})]^{+}$ & & - & - & $281(18)$ & - & $250(38)$ & $250(5$ & $251(14)$ & 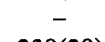 \\
\hline$[M-\mathrm{SC}-\mathrm{ROH}-\mathrm{Me}-(\mathrm{H})]^{+}$ & & - & - & - & $282(15)$ & $235(30)$ & $235(9)$ & $237(28)$ & $238(28)$ \\
\hline$\left[M-\mathrm{SC}-\mathrm{ROH}-\mathrm{C}_{3} \mathrm{H}_{6}-\mathrm{Me}+(\mathrm{H})\right]^{+}$ & & - & - & $227(25)$ & $241(35)$ & 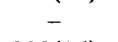 & - & - & - \\
\hline$\left[M-\mathrm{SC}-\mathrm{ROH}-\mathrm{C}_{3} \mathrm{H}_{6}\right]^{+}$ & & $211(25)$ & $213(18)$ & $241(26)$ & - & $209(16)$ & $207(12)$ & - & - \\
\hline
\end{tabular}

* Structures shown in Fig. 1.

† Me, 15 (loss of methyl); $\mathrm{C}_{3} \mathrm{H}_{7}, 43$ (loss of C-25 to C-27); $\mathrm{ROH}, 90$ (loss of $\mathrm{Me}_{3} \mathrm{SiOH}$ ); 84 (loss of C-23 to C-28 in 24 methylene side-chain); $\mathrm{SC}$ (loss of side chain); 131 (loss of $\mathrm{C}-1$ to $\mathrm{C}-3$ ); $\mathrm{C}_{3} \mathrm{H}_{6}, 42$ (loss of $\mathrm{C}-15$ to $\mathrm{C}-17$ ).

sterol TMS derivatives showing characteristic fragments $[M-\mathrm{SC}-\mathrm{ROH}-\mathrm{Me}]^{+}$and $[M-\mathrm{Me}-\mathrm{ROH}]^{+}$(where $\mathrm{SC}$ denotes the side-chain). Further, the TMS ethers of sterols $\mathrm{G}$ and $\mathrm{H}$ display fragments $[M-\mathrm{SC}-\mathrm{ROH}]^{+}$and $[M-\mathrm{SC}]^{+}$which also are typical of $\Delta^{8,14}$-sterol derivatives (Rahier \& Benveniste, 1989) (Table 2). Sterol H (comprising $13 \%$ of total sterols) as its trimethylsilyl ether has a molecular mass ion of $m / z 470$, indicating that it is a $\mathrm{C}_{28}$ dienol. The lack of a fragment corresponding to $[M-\mathrm{SC}-2 \mathrm{H}]^{+}$indicates that the side chain is unsaturated, while the $[M-\mathrm{SC}-\mathrm{ROH}-\mathrm{Me}]^{+}$fragment at $m / z 238$ shows that the mass of the side chain is 127 . This information, in addition to the UV spectrum, and comparison with published data (Loeffler \& Hayes, 1990), shows that sterol $\mathrm{H}$ is consistent with ergosta-8,14dien-3 $\beta$-ol (ignosterol).

The predominant sterol $\mathrm{G}(43 \%$ of total sterols) in erg- 3 has an additional double bond as indicated by its trimethylsilyl ether molecular ion at $\mathrm{m} / \mathrm{z}$ 468. The occurrence of fragments $[M-84-\mathrm{Me}]^{+}$at $m / z 369$ and $[M-84-\mathrm{ROH}-\mathrm{Me}]^{+}$at $m / z 279$ indicates the presence of a 24(28) double bond in the side chain, these fragments arising due to allylic cleavage of the $22-23$ bond by McLafferty-type rearrangement (Rahier \& Benveniste, 1989). These data are consistent with sterol $G$ being ergosta-8,14,24(28)-trien-3 $\beta$-ol (Girling et al., 1988).

Sterol E, comprising $25 \%$ of the total sterols in erg-3, has a trimethylsilyl molecular ion of $m / z 466$ which indicates that the sterol is a tetraene. The occurrence of fragment $[M-84-\mathrm{ROH}-\mathrm{Me}]^{+}$at $m / z 277$ indicates the presence of a $24(28)$ double bond in the side-chain, but the location of the fourth double bond is difficult to determine. The base peak $[M-\mathrm{Me}-\mathrm{ROH}]^{+}$at $m / z 361$ $(100 \%)$ is characteristic of a $\Delta^{5,8}$-sterol (Rahier \& Benveniste, 1989), and so the fourth double bond could be located at $\mathrm{C}-5=6$. Although not confirmed, sterol $\mathrm{E}$ is tentatively identified as ergosta-5,8,14,24(28)-tetraene$3 \beta$-ol.

Sterol F ( $6 \%$ of total sterols in erg- 3$)$ has a molecular ion at the same $m / z$ value as sterol $E(m / z 466)$ and a similar fragmentation pattern. However, the signal was very small and it could not be characterized further. Minor peaks corresponding to obtusifoliol $(4 \%$ of total sterols) and 24-methylenedihydrolanosterol $(1 \%$ of total sterols) were also detected in the erg-3 mutant.

Since most of the sterols isolated from the erg-3 mutant are $\Delta^{8,14}$-conjugated-diens, the mutant must be defective/deficient in $\Delta^{14,15}$-reductase activity. Presumably, erg-3 is the structural gene encoding this enzyme. To our knowledge, this is the first description in the literature of such a biochemical lesion in a fungal sterol mutant. It should be possible to confirm the absence of $\Delta^{14,15}$. reductase activity in the mutant by measuring enzyme activity directly in cell-free preparations using the assay described by Bottema \& Parks (1978). The defective $\Delta^{14,15}$-reductase would appear to prevent $\Delta^{8 \rightarrow 7}$-isomerase activity, indicating the requirement of a saturated bond at C-14-15 for isomerase activity. However, both $\Delta^{5,6}$ dehydrogenase and 24(28)-hydrogenase activities seem to be partially functional.

The defect at $\Delta^{14,15}$-reductase mimics the action of certain sterol biosynthesis inhibitors such as 
fenpropidin, 15-azasterol and azadecalins. These compounds inhibit $\Delta^{14,15}$-reductase (Baloch \& Mercer, 1987; Bottema \& Parks, 1978; Taton et al., 1989) and result in the accumulation of $\Delta^{8,14}$-dien-sterols (Mercer, 1988; Taton et al., 1989).

The $\Delta^{14,15}$-reductase mutant (erg-3) could be of value in the analysis of sterol biosynthesis inhibition by morpholine and piperidine fungicides. Studies are in progress to determine the effect of tridemorph, fenpropimorph and fenpropidin on growth and sterol composition of erg-3. Molecular biology studies to clone the $\Delta^{14,15}$-reductase gene by complementation of the erg-3 mutant are also in progress.

We are pleased to acknowledge receipt of GC-MS data on the erg-3 mutant from T. Wiggins, ICI Plant Protection Division.

\section{References}

BALOCH, R. I. \& MERCER, E. I. (1987). Inhibition of sterol $\Delta^{8-} \Delta^{7}$ isomerase and $\Delta^{14}$-reductase by fenpropimorph, tridemorph and fenpropidin in cell-free enzyme systems from Saccharomyces cerevisiae. Phytochemistry 26, 663-668.

Bard, M., Woods, R. A., Barton, D. H. R., Corrie, J. E. T. \& WidDowson, D. A. (1977). Sterol mutants of Saccharomyces cerevisiae: chromatographic analyses. Lipids 12, 645-654.

BotTema, C. K. \& Parks, L. W. (1978). $\Delta^{14}$-Sterol reductase in Saccharomyces cerevisiae. Biochemica et Biophysica Acta 531, 301-307.

Fryberg, M., Oehlschlager, A. C. \& Unrau, A. M. (1974). Sterol biosynthesis in antibiotic-resistant yeast: nystatin. Archives of Biochemistry and Biophysics 160, 83-89.

GiRling, I. J., Hollomon, D. W., Kendall, S. J., LoefFleR, R. S. T. \& SENIOR, I. J. (1988). Effects of fenpropidin on DMI-resistant strains of Erysiphe graminis $\mathrm{f}$. sp. hordei and Rhynchosporium secalis. Proceedings of the British Crop Protection Conference - Pests and Diseases, 385-390.
Grindle, M. (1973). Sterol mutants of Neurospora crassa: their isolation, growth characteristics and resistance to polyene antibiotics. Molecular and General Genetics 120, 283-290.

GRINDLE, M. (1974). The efficacy of various mutagens and polyene antibiotics for the induction and isolation of sterol mutants of Neurospora crassa. Molecular and General Genetics 130, 81-90.

GrindLE, M. \& FARRow, R. (1978). Sterol content and enzyme defects of nystatin-resistant mutants of Neurospora crassa. Molecular and General Genetics 165, 305-308.

Gollub, E. G., Trocha, P. K., LiU, P. K. \& Sprinson, D. B. (1974) Yeast mutants requiring ergosterol as only lipid supplement. Biochemical and Biophysical Research Communications 56, 471-477.

Howell, S. A., Moore, M. K., Mallet, A. I. \& Noble, W. C. (1990) Sterols of fungi responsible for superficial skin and nail infection. Journal of General Microbiology 136, 241-247.

LOEFFLER, R. S. T. \& HAYES, A. L. (1990). Sterols of the plant pathogenic fungi Botrytis cinerea and Pyrenophora teres. Phytochemistry 11, 3423-3425.

MERCER, E. I. (1984). The biosynthesis of ergosterol. Pesticide Science 15, 133-155.

MerCer, E. I. (1988). The mode of action of morpholines. In Sterol Biosynthesis Inhibitors, pp. 120-150. Edited by D. Berg \& M. Plempel. Chichester: Ellis Horwood.

Osumi, T., Taketani, S., Katsuki, H., Kuhara, T. \& Matsumoto, I. (1978). Ergosterol biosynthesis in yeast. Journal of Biochemsitry 83, 681-691.

Parks, L. W., Bottema, C. D. K., Rodrigues, R. J. \& Lewis, T. A. (1985). Yeast sterols: yeast mutants as tools for the study of sterol metabolism. Methods in Enzymology 111, 333-346.

RAHIER, A. \& BENVENISTE, P. (1989). Mass spectral identification of phytosterols. In Analysis of Sterols and Other Biologically Significant Sterols, pp. 223-250. Edited by W. D. Nes \& E. J. Parish. London: Academic Press.

Taton, M., Benveniste, P. \& Rahier, A. (1989). Microsomal $\Delta^{8,14}$ sterol $\Delta^{14}$-reductase in higher plants. European Journal of Biochemistry 185, 605-614.

Trocha, P. J., JASNe, S. J. \& SPRinson, D. B. (1977). Yeast mutants blocked in removing the methyl group of lanosterol at C-14. Separation of sterols by high-pressure liquid chromatography. Biochemistry 16, 4721-4726.

VOGEL, H. J. (1964). Distribution of lysine pathways among fungi : evolutionary implications. American Naturalist 98, 435-446.

WEETE, J. D. (1989). Structure and function of sterols in fungi. Advances in Lipid Research 23, 115-167. 